\title{
Site-fidelity and movement patterns of bottlenose dolphins (Tursiops truncatus) in central Argentina: essential information for effective conservation
}

\author{
ELS VERMEULEN ${ }^{\mathrm{a}, \mathrm{b}, \mathrm{c}, *}$, ALEJANDRO BALBIANO $^{\mathrm{d}}$, FLORENCIA BELENGUER $^{\mathrm{e}}$, DANIEL COLOMBIL $^{\mathrm{f}}$, \\ MAURICIO FAILLA $^{\mathrm{g}}$, EDGARDO INTRIERI ${ }^{\mathrm{f}}$ and STEFAN BRÄGER ${ }^{\mathrm{h}}$ \\ ${ }^{a}$ Sea Search Research and Conservation, Muizenberg, Cape Town, South Africa \\ ${ }^{\mathrm{b}}$ Laboratory of Oceanology, MARE Research Centre, University of Liège, Belgium \\ ${ }^{\mathrm{c}}$ Mammal Research Unit, University of Pretoria, South Africa \\ ${ }^{\mathrm{d}}$ Los Biologos, Capital Federal, Buenos Aires, Argentina \\ ${ }^{\mathrm{e}}$ Fótografias de Mascotas, Bahía Blanca, Buenos Aires, Argentina \\ ${ }^{\mathrm{f}}$ Penélope Pesca Embarcado, Bahía San Blas, Buenos Aires, Argentina \\ ${ }^{\mathrm{g}}$ Fundación Cethus, Olivos, Buenos Aires, Argentina \\ ${ }^{\mathrm{h}}$ International Seabed Authority, Kingston, Jamaica
}

\begin{abstract}
1. The effectiveness of conservation measures such as marine protected areas (MPAs) for the conservation of cetaceans is determined by how well their home range or critical habitat is covered. The present study seeks to provide information on the site-fidelity and movement patterns of individual bottlenose dolphins (Tursiops truncatus) in central Argentina.

2. Between 2007 and 2013, photo-identification data of bottlenose dolphins were collected in four study sites some $90-200 \mathrm{~km}$ apart from each other along the central Argentinean coast.

3. Results show long-term site-fidelity (over 5 years) in one of the study areas. Re-sighting rates further suggest the existence of different sub-populations of bottlenose dolphins, but also confirm some connectivity (with movements over 200-290 km) and thus potential for gene flow within the region.

4. Considering the population declines of bottlenose dolphins in Argentina, information on site-fidelity and movement patterns will be of value to improve the effectiveness of existing MPAs for the conservation of the species as well as prioritizing areas for increased research.

Copyright (C) 2016 John Wiley \& Sons, Ltd.
\end{abstract}

Received 26 January 2015; Revised 28 September 2015; Accepted 06 December 2015

KEY WORDS: coastal; estuary; marine protected area; dispersal; habitat management; mammal

*Correspondence to: Els Vermeulen, Sea Search Research and Conservation, 4 Bath Road, Muizenberg 7945, Cape Town, South Africa. Email: elsvermeulen5@gmail.com 


\section{INTRODUCTION}

For decades, bottlenose dolphins have been among the most frequently observed cetacean species in Argentinean coastal waters (Würsig, 1978; Würsig and Würsig, 1979). Since the 1980s, however, this situation has changed. Increased research in Argentina (Bastida and Rodríguez, 2003; Vermeulen and Cammareri, 2009; Coscarella et al., 2012; Fruet et al., 2014; Vermeulen and Bräger, 2015) has revealed serious population declines over past decades and an apparent population fragmentation for the species in this part of the south-west Atlantic. In Argentina, nowadays only infrequent and isolated observations of bottlenose dolphins are reported from areas where they were once very common (Bahía Samborombón and Bahía Blanca: Bastida and Rodríguez, 2003; Peninsula Valdés: Coscarella et al., 2012; Bahía Engaño: Coscarella and Crespo, 2009; see also Figure 1). Currently, sightings remain common only in central Argentina (Vermeulen and Cammareri, 2009), although numbers in this region also appear to be declining (e.g. only 40-83 individuals left in Bahia San Antonio in 2009-2011 according to Vermeulen and Bräger, 2015).

Conservation strategies for marine species frequently concentrate on the protection of limited geographical areas through the creation of marine protected areas (MPAs). However, this may be ineffective for cetaceans owing to their high dispersal capabilities (Hoelzel, 1994; Agardy et al., 2003). Generally, the degree of protection a MPA affords can be assessed as a function of species' dispersal distance and site-fidelity (Kenchington, 1990). As gene flow and area-based mitigation measures depend on mobility and connectivity, the movement patterns of a species play a key role in conservation. Therefore, the present study seeks to provide information on the site-fidelity and movement patterns of individual bottlenose dolphins in central Argentina based on photographic identification. In light of these data, the currently established conservation efforts for the species in the country are discussed.

\section{METHODS}

\section{Study areas}

Bahía San Antonio (BSA, 4045'S 6454'W; Figure 1) is a shallow bay $(<30 \mathrm{~m})$, located to the north-west of the San Matías Gulf (SMG). An MPA was created in this bay in 1993 (Provincial law of Río Negro $N^{\circ}$ 2670/93). As its main focus is based on the ecology of shorebirds, the jurisdiction of the MPA was limited to the intertidal zone, i.e. only to the low-tide mark. However, this was changed in 2008, when limits were moved to increase the marine surface covered by the MPA from $99 \mathrm{~km}^{2}$ to $597 \mathrm{~km}^{2}$

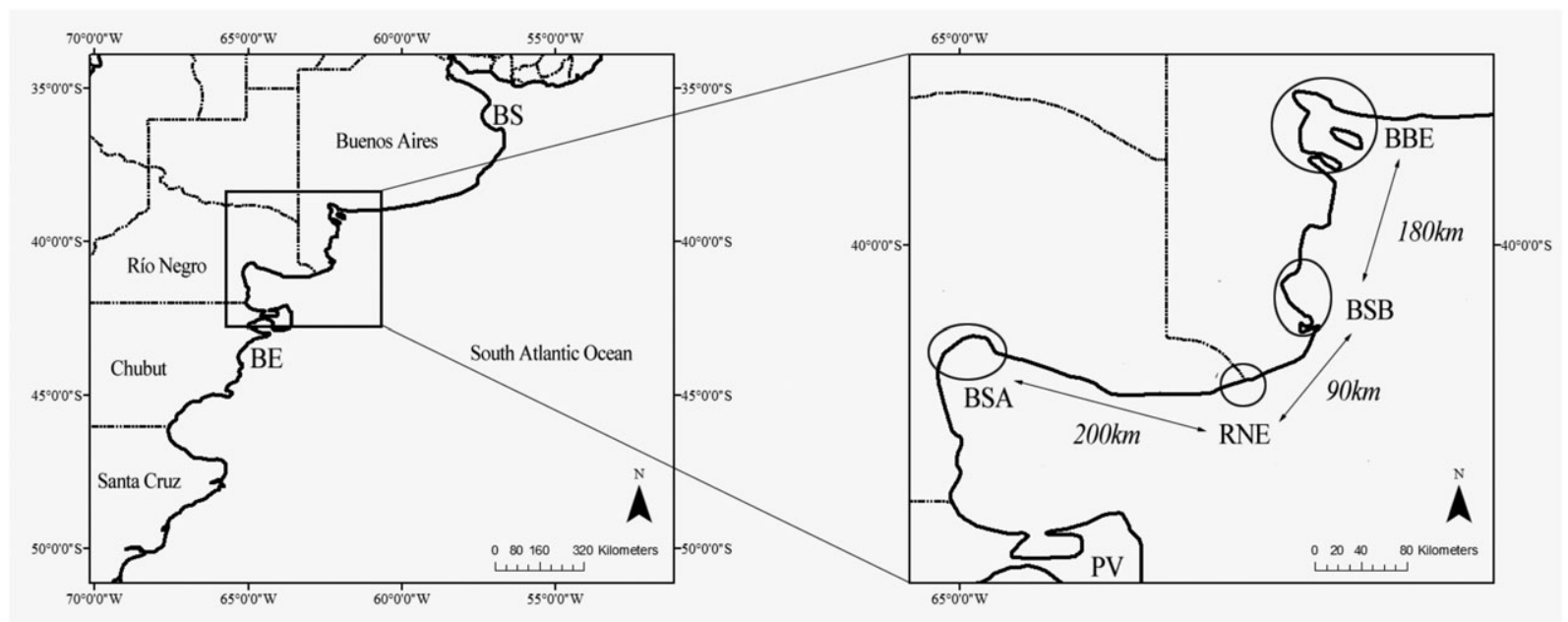

Figure 1. Map indicating the four study areas Bahía San Antonio (BSA), Río Negro Estuary (RNE), Bahía San Blas (BSB) and Bahía Blanca Estuary (BBE). Distances along the coastline are presented. Extralimital locations where bottlenose dolphins have been observed, although only rarely and in low numbers, are also indicated (i.e. Bahía Samborombón (BS), Península Valdés (PV) and Bahía Engaño (BE)). 
(Giaccardi, 2014). Owing to the importance of the area for migrating shorebirds, it was internationally recognized as a 'Western Hemisphere Shorebird Reserve Network Site' (González et al., 1996). Although commercial fishing activities have been limited, the area is still designated for 'multiple use' and includes a deep water port (Puerto San Antonio Este), a chemical plant producing sodium carbonate as well as artisanal and recreational fishing, whale- and dolphin-watching activities and the frequent presence of recreational water users (e.g. jet-skis, motorboats) (Giaccardi and Reyes, 2012).

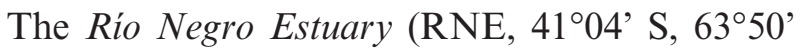
$\mathrm{W})$ is an area with turbid waters, islands, sandbars, channels and saltmarshes, located at the north-eastern border of the SMG. The Río Negro River, the longest river in Patagonia, discharges into this region and separates the Provinces of Buenos Aires and Río Negro politically from each other. Although not included in an MPA, this estuary is located adjacent to the MPA Punta Bermeja created primarily to protect a large colony of South American sea lions (Otaria flavescens) (Giaccardi, 2014).

Bahía San Blas (BSB, 4040’S, 62 ${ }^{\circ} 10^{\prime} \mathrm{W}$ ) is located in the southernmost part of the Province of Buenos Aires. It is a coastal marsh zone that also includes a group of five islands and sand embankments. In 1987 an MPA was first established within this region (Provincial law of Buenos Aires $\mathrm{N}^{\circ} 10.492 / 87$ ), after which it was designated as of 'multiple-use' in 2001 (Provincial law of Buenos Aires $\left.N^{\circ} 12.788 / 01\right)$. Subsequently, the Provincial law of Buenos Aires $N^{\circ} 13.366 / 05$ allowed artisanal and recreational fishing activities into the area in 2005. The jurisdiction of the MPA includes a sea area of $2350 \mathrm{~km}^{2}$ (Giaccardi and Tagliorette, 2007; Sotelo and Massola, 2008; Giaccardi, 2014). The area is now very popular for recreational fishing activities because of the high productivity in the area (Lucifora, 2003).

Bahía Blanca Estuary (BBE, $39^{\circ} 25^{\prime} \mathrm{S}, 61^{\circ} 15^{\prime} \mathrm{W}$ ) is located in the south of the Province of Buenos Aires. It is a large and complex estuary system with periods of high freshwater inflow from the
Río Colorado River (Piccolo and Perillo, 1990). It is the second largest and the most complex estuary system in the country. A large number of channels separated by islands and wide tidal flats give it physical characteristics that vary significantly from all other estuary systems in South America (Piccolo and Perillo, 1990). Despite the presence of Argentina's second largest port and a large urban area (>300 000 inhabitants), the islands and marshes in this estuary were included in an MPA established in 1998 (Provincial law of Buenos Aires $\left.\mathrm{N}^{\circ} 12.101 / 98\right)$. The MPA is designated to be of 'multiple use', and covers a total water surface of $1800 \mathrm{~km}^{2}$ (Giaccardi and Tagliorette, 2007 ; Giaccardi, 2014).

\section{Data collection}

A standard photo-identification method (Würsig and Würsig, 1977) was used to photograph as many dorsal fin profiles as possible regardless of the presence of obvious marks. Such images were taken using a digital SLR camera with a 200-400 $\mathrm{mm}$ zoom lens, and aimed to capture the long-lasting natural marks on the dolphins' dorsal fins used for individual identification (Würsig and Jefferson, 1990). Dolphins identified to be closely accompanied by a calf on at least two different occasions were assumed to be females (Mann and Smuts, 1999; Grellier et al., 2003). The sex of 14 other dolphins identified in BSA was determined through genetic analysis of well-marked and sampled individuals (Fruet et al., 2014). Adults were defined by their large size, darker coloration and a higher number of permanent marks on the edge of their dorsal fins and flanks, whereas immatures were defined as individuals of similar size to an adult but with a lighter coloration and an overall lack of severe scars and marks on their dorsal fins and flanks. Furthermore, the latter were no longer in close association with an adult.

In total, 326 systematic photo-identification surveys for bottlenose dolphins were conducted in BSA between 2007 and 2011. Of these surveys, 197 were land-based and 129 were conducted from a small, outboard-powered inflatable boat. These boat-based surveys followed randomly chosen survey tracks, covering at least half of the study 
area each time. The total effort resulted in $1390 \mathrm{~h}$ during which 386 dolphin groups were observed and $>10000$ dorsal fin pictures were obtained for individual identification purposes. Furthermore, additional mark-recapture data were obtained opportunistically on 30 other occasions, i.e. not during dedicated surveys (Table 1).

Outside BSA, survey effort was reduced resulting in 4356 photo-identification pictures collected between 2007 and 2013, using digital SLR cameras. Of these images, 110 were taken in BBE, 46 in BSB and 4200 in RNE (Figure 1). The number of daily surveys during which these pictures were collected, as well as the number of identifications and re-sightings from each study site, is detailed in Table 1. In these three north-eastern study areas, photo-identification pictures were taken more infrequently and not all seasons are represented equally.

\section{Analyses}

Image quality was graded 1 (poor quality) to 3 (excellent quality) based on light, focus, distance, water spray covering the dorsal fin and angle of the dorsal fin (Wilson et al., 1999). Only grade 3 photographs (dorsal fin perpendicular to frame, no water spray, in focus, close distance (i.e. dorsal fin is at least $1 / 3$ of the picture frame) and sufficient light) were further used in analyses to ensure sufficient quality to correctly identify the individual dolphins. Photographs taken during land- and boat-based surveys were used in the analysis.

Residency and site-fidelity were estimated for all identified individuals from the BSA study population that was most extensively observed. To do so, a Residency Index (RI) (Koelsh, 1997; Simões-Lopes and Fabian, 1999; Quintana-Rizzo

Table 1. Total number of days with (systematic/opportunistic) photo-identification effort and total number of identifications in Bahía San Antonio $(B S A ; n=356)$, Río Negro Estuary (RNE; $n=117)$, Bahía San Blas (BSB; $n=3$ ) and Bahía Blanca Estuary $(B B E ; n=14)$ by season

\begin{tabular}{|c|c|c|c|c|c|c|c|c|c|c|c|c|}
\hline & & & 2007 & 2008 & 2009 & 2010 & 2011 & 2012 & 2013 & SUM & $\begin{array}{c}\text { Seasonal total } \\
\text { effort }\end{array}$ & $\begin{array}{l}\text { Seasonal total } \\
\text { identifications }\end{array}$ \\
\hline \multirow[t]{4}{*}{ Summer } & BSA & survey days & 8 & 45 & 18 & 4 & $19 / 1$ & 0 & 0 & $94 / 1$ & \multirow[t]{4}{*}{105} & \multirow[t]{4}{*}{250} \\
\hline & RNE & identifications & 0 & 1 & 0 & 4 & 0 & 0 & 2 & 7 & & \\
\hline & \multirow[t]{2}{*}{ BSB } & survey days & 0 & 0 & 0 & 0 & 0 & 0 & 0 & 0 & & \\
\hline & & identifications & 0 & 0 & 0 & 0 & 0 & 0 & 0 & 0 & & \\
\hline \multirow[t]{7}{*}{ Autumn } & \multirow[t]{2}{*}{ BSA } & survey days & 41 & $11 / 1$ & $26 / 3$ & $3 / 3$ & 9 & 0 & 0 & $90 / 7$ & \multirow[t]{7}{*}{197} & \multirow[t]{7}{*}{307} \\
\hline & & identifications & 53 & 14 & 51 & 20 & 13 & 0 & 0 & 151 & & \\
\hline & \multirow[t]{2}{*}{ RNE } & survey days & $0 / 4$ & $0 / 8$ & $0 / 8$ & $0 / 27$ & $0 / 16$ & $0 / 21$ & $0 / 10$ & $0 / 94$ & & \\
\hline & & identifications & 11 & 14 & 13 & 80 & 22 & 4 & 6 & 150 & & \\
\hline & \multirow[t]{2}{*}{ BSB } & survey days & 0 & 0 & 0 & 0 & 0 & 0 & $0 / 1$ & $0 / 1$ & & \\
\hline & & identifications & 0 & 0 & 0 & 0 & 0 & 0 & & 0 & & \\
\hline & BBE & survey days & 0 & 0 & $0 / 2$ & $0 / 1$ & 0 & $0 / 1$ & $0 / 1$ & $0 / 5$ & & \\
\hline & & identifications & 0 & 0 & 0 & 3 & 0 & 3 & 2 & 8 & \multirow{5}{*}{138} & \multirow{5}{*}{684} \\
\hline & \multirow[t]{2}{*}{ BSB } & survey days & 0 & 0 & 0 & 0 & 0 & 0 & $0 / 1$ & $0 / 1$ & & \\
\hline & & identifications & 0 & 0 & 0 & 0 & 0 & 0 & 0 & 0 & & \\
\hline & \multirow[t]{2}{*}{ BBE } & survey days & 0 & 0 & $0 / 1$ & 0 & $0 / 1$ & $0 / 1$ & 0 & $0 / 3$ & & \\
\hline & & identifications & 0 & 0 & 0 & 0 & 2 & 1 & 0 & 3 & & \\
\hline \multirow[t]{8}{*}{ Spring } & \multirow[t]{2}{*}{ BSA } & survey days & 11 & $16 / 3$ & $4 / 1$ & 6 & $0 / 3$ & 0 & 0 & $37 / 7$ & \multirow[t]{8}{*}{50} & \multirow[t]{8}{*}{100} \\
\hline & & identifications & 8 & 7 & 42 & 26 & 2 & 0 & 0 & 85 & & \\
\hline & \multirow[t]{2}{*}{ RNE } & survey days & 0 & 0 & 0 & 0 & 0 & 0 & 0 & 0 & & \\
\hline & & identifications & 0 & 0 & 0 & 0 & 0 & 0 & 0 & 0 & & \\
\hline & \multirow[t]{2}{*}{ BSB } & survey days & 0 & 0 & 0 & 0 & 0 & 0 & $0 / 1$ & $0 / 1$ & & \\
\hline & & identifications & 0 & 0 & 0 & 0 & 0 & 0 & 5 & 5 & & \\
\hline & BBE & survey days & 0 & $0 / 1$ & $0 / 1$ & $0 / 1$ & 0 & 0 & $0 / 2$ & $0 / 5$ & & \\
\hline & & identifications & 0 & 0 & 2 & 0 & 0 & 0 & 8 & 10 & & \\
\hline
\end{tabular}


and Wells, 2001; Lusseau, 2005; Lodi et al., 2008) was calculated as the proportion of the number of months an individual was re-sighted and the number of months with sufficient survey effort (i.e. a minimum of three fieldtrips was chosen conservatively to eliminate months with potentially insufficient coverage of only one or two surveys; $n=45$ ). The distribution of RI values of all individuals was corrected for effort and tested against a Poisson distribution; a Kruskall-Wallis test was used to compare the RI values among years and seasons. Pearson's Correlation Coefficient was used to explore the relation between the individual RI values and the number of years dolphins were re-sighted in BSA.

Movement patterns were assessed through the re-sighting of individuals in different study areas. To correct for any bias due to the high variability in survey effort among the four different study areas, an expected sighting rate was calculated for each individual in each area based on the survey effort within each area (Bräger et al., 2002; Silva et al., 2012) using the equation

$$
\mathrm{E}_{\mathrm{ij}}=\mathrm{n}_{\mathrm{i}} \times \frac{\mathrm{s}_{\mathrm{j}}}{\mathrm{S}}
$$

where $E_{i j}=$ the expected sighting rate of bottlenose dolphin $\mathrm{i}$ in study area $\mathrm{j}, \mathrm{n}_{\mathrm{i}}=$ total number of sightings of bottlenose dolphin $\mathrm{i}, \mathrm{s}_{\mathrm{j}}=$ number of surveys in study area $\mathrm{j}$, and $\mathrm{S}=$ total number of surveys. A log-likelihood ratio goodness-of-fit test was then used to compare the observed sighting rates with the expected sighting rates determined from effort data. Based on the individuals identified in BSA, Pearson's Correlation Coefficient was calculated to explore the relationship between the number of years an individual was re-sighted in BSA (as a measure of site-fidelity) and the observed distance it travelled from BSA. The same analysis was conducted to evaluate the relationship between the RI values of each individual identified in BSA and the distance it travelled from BSA. In order to assess the extent of movements, the shortest distances along the coastline (i.e. without crossing land) between different sighting locations were measured using the software program ESRI ArcGIS 10.1.

\section{RESULTS}

\section{Residency and seasonal site-fidelity in Bahía San Antonio}

In BSA, 67 bottlenose dolphins were individually identified up to 44 times on separate days $($ median $=16 ; \quad$ mean $=17.6 ; \quad \mathrm{SD}=11.1) . \quad$ Most individuals were identified for the first time in the first two study years after which the identification of new individuals gradually levelled off. By the end of the study, the identification catalogue for BSA contained 67 individuals including 16 adult females, 10 adult males, two immature males, eight immatures of unknown sex and 31 adults of unknown sex. In total, $78 \%$ of these individuals $(n=52)$ were re-sighted in every study year since their first identification. No calves were included in the catalogue as their low number of marks reduces their reliable identification.

The median RI value of all 67 identified dolphins in the BSA study area combined (2007-2011) was $0.24(\mathrm{Q} 1=0.11 ; \mathrm{Q} 3=0.36$ ), ranging from 0.0 (for any individual that was seen only once, and thus was never re-sighted) to 0.56 (for an individual that was re-sighted in 25 of the 45 study months), and did not follow a Poisson distribution $(\lambda=25.7$, $\left.\chi^{2}=68.4, d f=2, P<0.01\right)$. Furthermore, the RI values appeared to be positively correlated with the number of years individuals were seen in BSA $\left(\mathrm{R}^{2}=0.53, \quad P<0.01\right.$; Figure 2$)$, indicating that dolphins which used the area more regularly throughout the year (i.e. seasonally) also tended to exhibit a higher between-year site-fidelity.

No significant difference was found in the RI values of all identified dolphins over the various research years $(\mathrm{K}-\mathrm{WH}=2.7, \quad d f=4, \quad P=0.6)$. However, when comparing the RI values of all individuals across seasons, dolphins were significantly more often present in winter than in any other season $(\mathrm{K}-\mathrm{WH}=23.2, d f=3, P<0.01$; Figure 3). In total, 28 individuals (43\% of the total number of identified individuals) were present in the study area during each winter season since they were first identified. Another 13 individuals were present in the BSA study area during all but one winter season since their first identification. Only two individuals were seen only in one winter season since their first identification. 


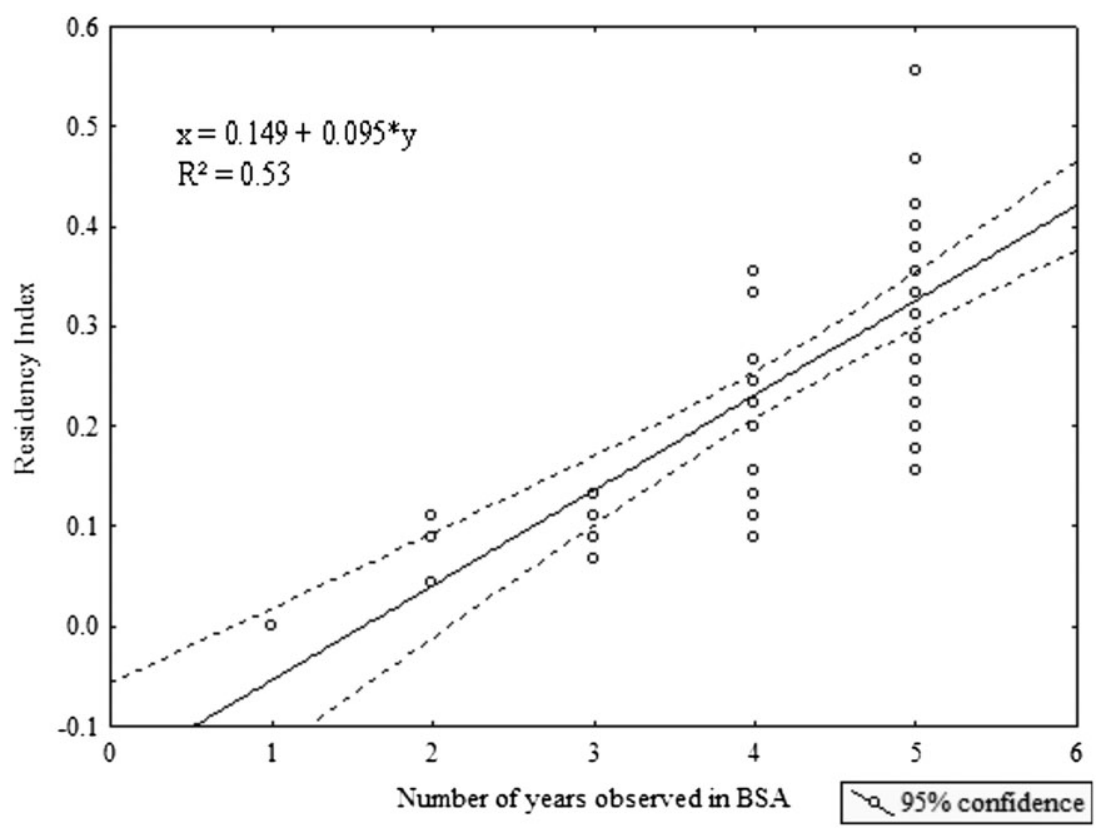

Figure 2. Correlation between the Residency Index value of 67 individual bottlenose dolphins and the number of years (2007-2011) these dolphins were observed in Bahía San Antonio (BSA), with 95\% CI.

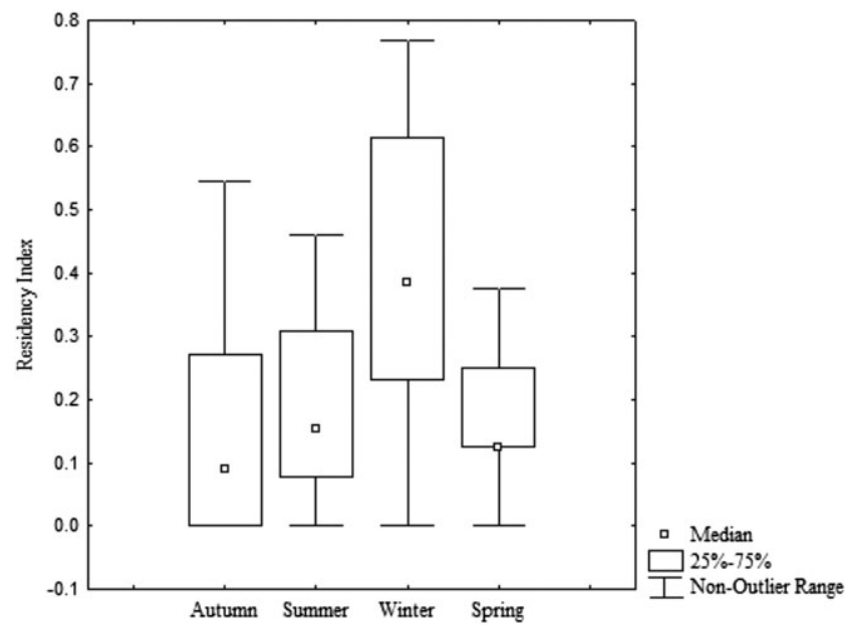

Figure 3. Seasonal variation in mean RI values of 67 identified bottlenose dolphins in Bahía San Antonio (BSA). The number of months per season was 13 each for summer and winter, 11 for autumn and 8 for spring.

\section{Ranging patterns}

In $\mathrm{BBE}$, photographs allowed the identification of 17 individual bottlenose dolphins. One of them was re-sighted in BBE in three different years, three other individuals were identified in $\mathrm{BBE}$ in two different years, and yet another one was subsequently re-sighted in BSB. The other 12 individuals were sighted only in $\mathrm{BBE}$ and within the same year.

In BSB, two new individuals could be identified and three other individuals were re-sighted from previous identifications in another study area. Of the latter, one individual was previously identified in BBE and the other two (both adults of unknown sex) were previously identified in BSA (one of which was also re-sighted in RNE).

In RNE, photographs taken allowed the new identification of one individual (sighted only once) as well as the re-sighting of 20 individual dolphins previously identified in BSA. Most of these were subsequently re-sighted on various occasions in both areas, with a minimum interval of 8 days between sightings in both areas (equivalent to a mean travel speed of $25 \mathrm{~km} \mathrm{day}^{-1}$ ). Three of these 20 individuals were reproductive females with associated calves, four adult males and one adult female without a calf. All other individuals were adults of unknown sex.

These data, combined with the photo-identification data from BSA, resulted in a total of 87 identified individuals, connecting all neighbouring study areas (Figure 4). 


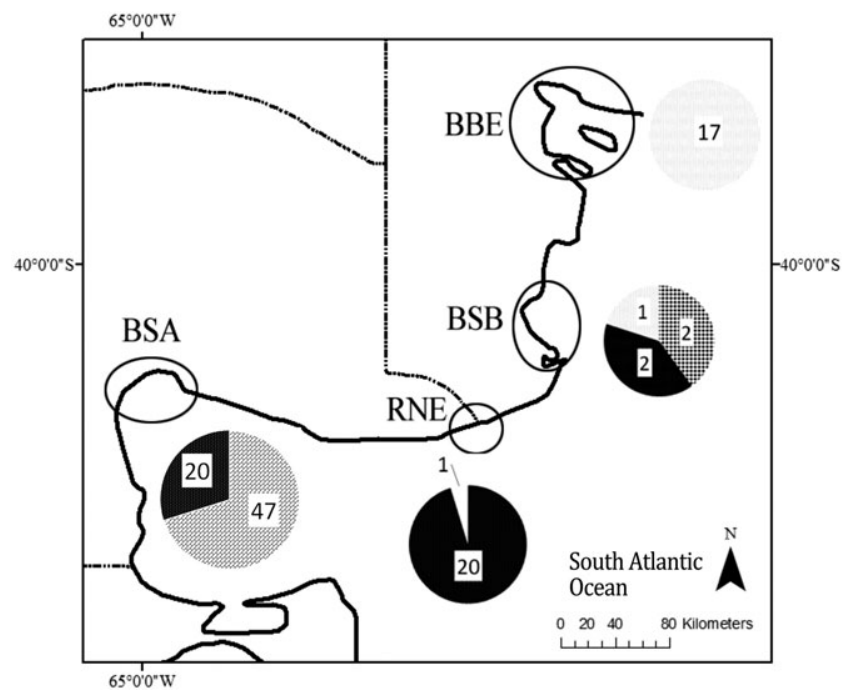

Figure 4. Connectivity among the study areas as indicated by the number of individuals identified in each region. Shadings indicate the individuals shared between the different regions $(\mathrm{BSA}=$ Bahía San Antonio, $\mathrm{RNE}=$ Río Negro Estuary, $\mathrm{BSB}=$ Bahía San Blas, $\mathrm{BBE}=$ Bahía Blanca Estuary).

The highest exchange rate of individuals per survey was found between BSB and BBE (5.9 individuals/100 surveys) and BSA and RNE (4.2 individuals/100 surveys). Exchange rates between all other regions dropped below 1 individual/100 surveys, regardless of distance (Figure 5).
Table 2. Median sighting rates (corrected for effort) of individual dolphins which tested significant $(P<0.01)$ in a log-likelihood ratio tests to investigate the goodness-of-fit of the geographical distribution of sightings to the geographical distribution of effort (BSA = Bahía San Antonio, RNE= Río Negro Estuary, BSB=Bahía San Blas, $\mathrm{BBE}=$ Bahía Blanca Estuary)

Median observed sighting rate (number of sightings/number of surveys)

\begin{tabular}{lllll}
\hline Number of individuals & BSA & RNE & BSB & BBE \\
\hline 22 & 0.07 & 0 & 0 & 0 \\
4 & 0.045 & 0.15 & 0 & 0 \\
1 & 0.06 & 0 & 0.33 & 0 \\
1 & 0.04 & 0.09 & 0.33 & 0 \\
1 & 0 & 0.01 & 0 & 0.14 \\
16 & 0 & 0 & 0 & 0.07 \\
2 & 0 & 0 & 0.5 & 0 \\
\hline
\end{tabular}

When accounting for the uneven distribution of survey effort, analysis showed that 47 of the 87 individuals $(54 \%)$ had a geographical distribution of sightings that was not explained by the geographical distribution of survey effort, indicating a site-fidelity to and/or avoidance of a particular area (Table 2). Assuming an even distribution, the exclusive sighting of 22 individuals only in BSA was unexpected considering the effort in the other regions. On the other hand, 19 individuals were never observed in BSA which was equally unexpected considering the good sampling effort in this area.

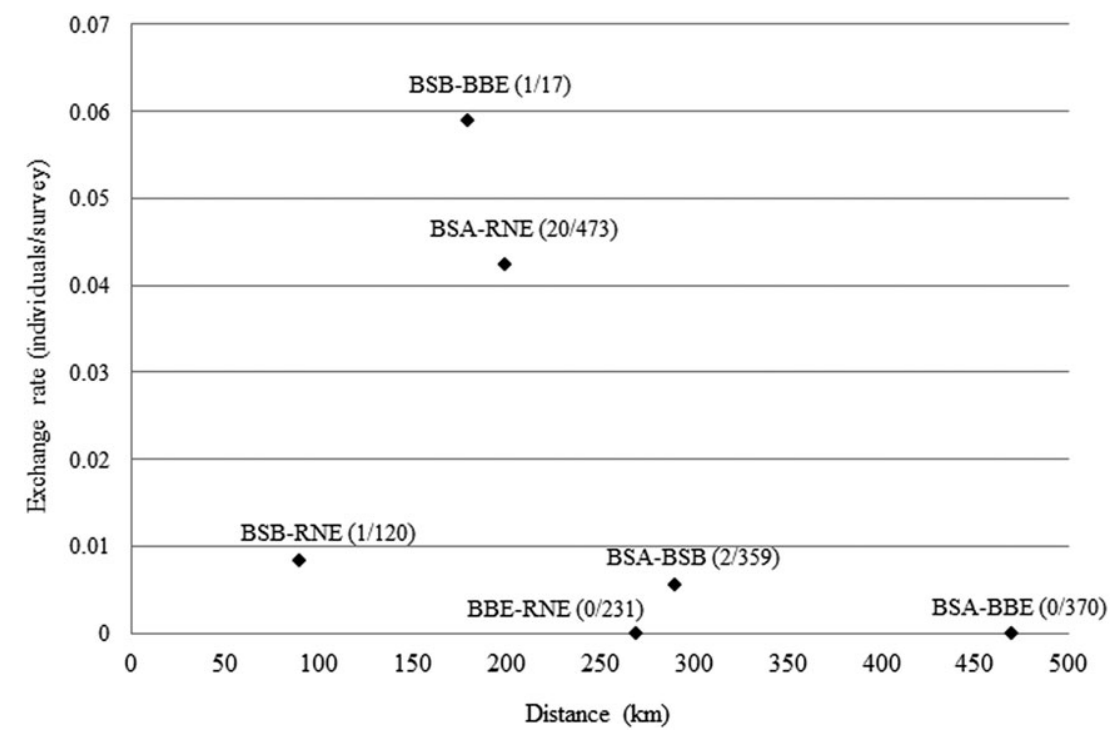

Figure 5. Connectivity among study sites expressed as the rate of exchanged individuals as a function of distance (between the four study sites; $\mathrm{BSA}=$ Bahía San Antonio, RNE = Río Negro Estuary, BSB = Bahía San Blas, BBE= Bahía Blanca Estuary). The number of exchanged individuals and the combined number of surveys are given in parentheses. 
Using data from the 67 animals identified in the main study area BSA, no correlation could be found between their RI values and the distance travelled from BSA $\left(\mathrm{R}^{2}=0.02, P=0.2\right)$, nor between the number of years an individual was seen in BSA and the distance travelled from BSA $\left(\mathrm{R}^{2}=0.01, \quad P=0.4\right)$. Similarly, no significant difference was found between the RI values of individuals known to range out of BSA versus the RI values of those individuals only re-sighted in BSA (Mann-Whitney $\mathrm{U}=345, P=0.22$ ).

\section{DISCUSSION}

Site-fidelity and movements of bottlenose dolphins in central Argentina provide evidence for long-term site-fidelity in at least one study area (BSA) over all five study years, while also ranging approximately $200 \mathrm{~km}$ along the northern coast of the SMG, with few other individuals covering similar distances $(180-290 \mathrm{~km})$ between other study sites as well. Although the movements of individuals out of BSA obviously affected their presence in this area during some time of the year, it did not appear to affect their year-round and long-term site-fidelity. The complete absence of re-sightings in BSA of another 19 dolphins identified only in BBE, however, was rather unexpected considering the concentration of sampling effort. The distance between BSA and BBE $(470 \mathrm{~km})$ is well within the maximum known ranging distances recorded for the species $(>500 \mathrm{~km}$ : Wells and Scott, 1990; Mate et al., 1995; Defran et al., 1999; $>1000$ km: Wood, 1998; Wells et al., 1999; O'Brien et al., 2009). The higher exchange rates between BSA and RNE in the southern, and BSB and BBE in the northern areas might support the existence of different sub-populations of bottlenose dolphins, that may well interact with each other in overlapping home ranges. Re-sighting rates in BSB were relatively high considering the small effort in this region, suggesting the possibility of a high degree of connectivity. Nonetheless, the low survey effort in the two study areas BSB and BBE suggests that - at least for now - the results should be interpreted with caution.

Bottlenose dolphins living in protected coastal environments with predictably available resources are often reported to display a high degree of residency and long-term site-fidelity while belonging to relatively small communities (Wells et al., 1987; Bearzi et al., 2008; Sprogis et al., 2015). At the same time, they constitute a highly mobile marine species (Wells et al., 1990) with high dispersal capabilities and long-range movements (Defran et al., 1999; Hwang et al., 2014) which is believed to promote genetic exchange between populations (Wells, 1991; Möller et al., 2002). There was a high degree of connectivity among the neighbouring study areas in central Argentina, which constitutes an important finding considering the suspected population fragmentation along the coast of Argentina owing to population declines (Vermeulen and Bräger, 2015). Whether or not these ranging patterns translate into genetic connectivity remains to be determined, and increased research efforts in areas outside BSA appear necessary for a better understanding of the bottlenose dolphin population structure in this part of the country.

Studies of animal movement patterns have been referred to by Stenseth and Lidicker (1992) as the 'glue between ecology, population genetics, ethology and evolution'. In additional, their results have strong implications for conservation management as such movement patterns will influence the size and effectiveness of protected areas (Hyrenbach et al., 2006). Area-based conservation measures such as the creation of MPAs have a long history in the conservation of marine mammals (Hoyt, 2011). Within Argentina, 59 MPAs were created in the 1990s, 30 of which are located in the distribution area of bottlenose dolphins (including the three study areas BSA, BSB and BBE; Tagliorette and Mansur, 2008; Giaccardi, 2014). However, they appear to have been ineffective so far in preventing the decline of bottlenose dolphin populations in the country (Vermeulen and Bräger, 2015). Since most marine mammals are highly mobile and can range over vast areas, the success of MPAs depends largely on how well their location corresponds to the population's home range (Hoelzel, 1994; Wilson et al., 2004; Hooker et al., 2011; Silva et al., 2012; Cheney et al., 2014) or critical habitat (Hoyt, 
2015). In a few coastal dolphin populations, MPAs have been shown to be effective when congruence is - at least largely - achieved (Bräger et al., 2002; Gormley et al., 2012). Therefore, these findings are believed to provide valuable information when improving the effectiveness of Argentine MPAs for the conservation of the bottlenose dolphin as well as prioritizing areas for increased research efforts on the species.

\section{ACKNOWLEDGEMENTS}

Thanks are due to Alejandro Cammareri and Fundación Marybio for help during the surveys in BSA. Special thanks to Mariela Pazos, Veronica Seijas, Pablo Petracci, Martin Sotelo, Gisela Giardino, Leonardo Russo Lacerna and Vanesa Reyes for providing additional photo-identification pictures. The Secretaría de Ambiente y Desarrollo Sustentable of the Río Negro Province is gratefully thanked for the necessary research permits. The Prefectura Naval Argentina de Carmen de Patagones provided logistical support. This study was funded by Cetacean Society International, Trigon NV, Fundación Marybio, Fundación Cethus and Whale and Dolphin Conservation. The manuscript was improved with helpful comments from Pedro Fruet and three anonymous reviewers. The views expressed in this paper are those of the authors and do not necessarily reflect the position of the International Seabed Authority.

\section{REFERENCES}

Agardy T, Bridgewater P, Crosby MP, Day J, Dayton PK, Kenchington R, Laffoley D, McConney P, Murray PA, Parks JE, Peau L. 2003. Dangerous targets? Unresolved issues and ideological clashes around marine protected areas. Aquatic Conservation: Marine and Freshwater Ecosystems 13: 353-367.

Bastida R, Rodríguez D. 2003. Mamiferos Marinos Patagonia Antartida, Vazquez Mazzini Editors: Buenos Aires, Argentina.

Bearzi G, Agazzi S, Bonizzoni S, Costa M, Azzellino A. 2008. Dolphins in a bottle: abundance, residency patterns and conservation of common bottlenose dolphins Tursiops truncatus in the semi-closed eutrophic Amvrakikos Gulf, Greece. Aquatic Conservation: Marine and Freshwater Ecosystems 18: 130-146.
Bräger S, Dawson SM, Slooten E, Smith S, Stone GS, Yoshinaga A. 2002. Site fidelity and along-shore range in Hector's dolphin, an endangered marine dolphin from New Zealand. Biological Conservation 108: 281-287.

Cheney B, Corkrey R, Durban JW, Grellier K, Hammond PS, Islas-Villanueva V, Janik VM, Lusseau SM, Parsons KM, Quick NJ, et al. 2014. Long-term trends in the use of a protected area by small cetaceans in relation to changes in population status. Global Ecology and Conservation 2: 118-128.

Coscarella MA, Crespo EA. 2009. Feeding aggregation and aggressive interaction between bottlenose (Tursiops truncatus) and Commerson dolphins (Cephalorhynchus commersonii) in Patagonia, Argentina. Journal of Ethology 28: 183-187.

Coscarella M, Dans SL, Degrati M, Garaffo GV, Crespo EA. 2012. Bottlenose dolphins at the southern extreme of the south-western Atlantic: local population decline? Journal of the Marine Biological Association of the United Kingdom 92: 1843-1849.

Defran RH, Weller DW, Kelly DL, Espinosa MA. 1999. Range characteristics of Pacific coast bottlenose dolphins (Tursiops truncatus) in the Southern Californian Bight. Marine Mammal Science 15: 381-393.

Fruet PF, Secchi ER, Daura-Jorge F, Vermeulen E, Flores PAC, Simões-Lopes PC, Genoves RC, Laporta P, Di Tullio JC, Freitas TRO, et al. 2014. Remarkably low genetic diversity and strong population structure in common bottlenose dolphins (Tursiops truncatus) from coastal waters of the Southwestern Atlantic Ocean. Conservation Genetics 15: 879-985.

Giaccardi M. 2014. Situación actual de las Áreas Protegidas Marino - Costeras de la Argentina, Informe Proyecto GEF 5112-FAO-Secretaria de Ambiente y Desarrollo Sustentable.

Giaccardi M, Reyes L. 2012. Plan de Manejo del Área Natural Protegida Bahía de San Antonio, Rio Negro, Gobierno de la provincia de Río Negro.

Giaccardi M, Tagliorette A. 2007. Efectividad del manejo de las áreas protegidas marino-costeras de la Argentina. Secretaría de Ambiente y Desarrollo Sustentable de la Nación, Fundación Patagonia Natural y Fundación Vida Silvestre Argentina: Buenos Aires.

González PM, Piersma T, Verkuil Y. 1996. Food, feeding, and refuelling of red knots during northward migration at San Antonio Oeste, Rio Negro, Argentina. Journal of Field Ornithology 67: 575-591.

Gormley AM, Slooten E, Dawson S, Barker RJ, Rayment W, du Fresne S, Bräger S. 2012. First evidence that marine protected areas can work for marine mammals. Journal of Applied Ecology 49: 474-480.

Grellier K, Hammond PS, Wilson B, Sanders-Reed CA, Thompson PM. 2003. Use of photo-identification data to quantify mother-calf association patterns in bottlenose dolphins. Canadian Journal of Zoology 81: 1421-1427.

Hoelzel AR. 1994. Genetics and ecology of whales and dolphins. Annual Review of Ecology and Systematics 25: 377-399.

Hooker SK, Cañadas A, Hyrenbach KD, Corrigan C, Polovina JJ, Reeves RR. 2011. Making protected area networks effective for marine top predators. Endangered Species Research 13: 203-218.

Hoyt E. 2011. Marine Protected Areas for Whales, Dolphins and Porpoises: A World Handbook for Cetacean Habitat Conservation and Planning, 2nd edn. Routledge/Earthscan. ISBN:978-1-84407-763-2. 
Hoyt E. 2015. Summary Proceedings of the Third International Conference on Marine Mammal Protected Areas (ICMMPA 3), Adelaide, Australia, 9-11 Nov. 2014.

Hwang A, Defran RH, Bearzi M, Maldini D, Saylan CA, Lang, AR, Dudzik KJ, Guzòn-Zatarain OR, Kelly DL, Weller DW. 2014. Coastal range and movements of common bottlenose dolphins (Tursiops truncatus) off California and Baja California, Mexico. Bulletin of the Southern California Academy of Sciences 113: Iss. 1. Available at: http://scholar. oxy.edu/scas/vol113/iss1/1.

Hyrenbach KD, Keiper C, Allen SG, Ainley DG, Anderson DJ. 2006. Use of marine sanctuaries by far-ranging predators: commuting flights to the California current system by breeding Hawaiian albatrosses. Fisheries Oceanography 15: 95-103.

Kenchington RA. 1990. Managing Marine Environments, Taylor and Francis: New York and London.

Koelsh JK. 1997. The seasonal occurrence and ecology of Florida manatees (Trichechus manatus latirostris) in coastal waters near Sarasota, Florida. $\mathrm{PhD}$ thesis, University of South Florida, USA.

Lodi L, Wedekin LL, Rossi-Santos MR, Marcondes MC. 2008. Movements of the bottlenose dolphin (Tursiops truncatus) in the Rio de Janeiro state, southeastern Brazil. Biota Neotropica 8: 205-209.

Lucifora LO. 2003. Ecología y conservación de los grandes tiburones costeros de Bahía Anegada, Provincia de Buenos Aires, Argentina. PhD thesis, University of Mar del Plata, Argentina.

Lusseau D. 2005. Residency pattern of bottlenose dolphins Tursiops spp. in Milford Sound, New Zealand, is related to boat traffic. Marine Ecology Progress Series 295: 265-272.

Mann J, Smuts B. 1999. Behavioural development in wild bottlenose dolphin newborns (Tursiops sp.). Behaviour 136: 529-566.

Mate BR, Rossbach KA, Nieukirk SL, Wells RS, Irvine AB, Scott MD, Read AJ. 1995. Satellite-monitored movements and dive behavior of a bottlenose dolphin (Tursiops truncatus) in Tampa Bay, Florida. Marine Mammal Science 11: $452-463$.

Möller LM, Allen SJ, Harcourt RG. 2002. Group characteristics, site fidelity and seasonal abundance of bottlenose dolphins (Tursiops aduncus) in Jervis Bay and Port Stephens, South-Eastern Australia. Australian Mammalogy 24: 11-22.

O'Brien JM, Berrow SD, Ryan C, McGrath D, O'Connor I, Pesante G, Burrows G, Massett N, Klötzer V, Whooley P. 2009. A note on long-distance matches of bottlenose dolphins (Tursiops truncatus) around the Irish coast using photo-identification. Journal of Cetacean Research and Management 11: 71-76.

Piccolo MC, Perillo GM. 1990. Physical characteristics of the Bahía Blanca estuary (Argentina). Estuarine, Coastal and Shelf Science 31: 303-317.

Quintana-Rizzo E, Wells RS. 2001. Resighting and association patterns of bottlenose dolphins (Tursiops truncatus) in the Cedar Keys, Florida: insights into social organization. Canadian Journal of Zoology 79: 447-456.

Silva MA, Prieto R, Magalhães S, Seabra MI, Machete M, Hammond PS. 2012. Incorporating information on bottlenose dolphin distribution into marine protected area design. Aquatic Conservation: Marine and Freshwater Ecosystems 22: 122-133.
Simões-Lopes PC, Fabian ME. 1999. Residence patterns and site fidelity in bottlenose dolphins (Tursiops tuncatus) (Montagu) (Cetacea, Delphinidae) off Southern Brazil. Revista Brasileira de Zoologia 16: 1017-1024.

Sotelo M, Massola V. 2008. Plan de manejo de la Reserva Natural Provincial de uso Múltiple Bahía Blanca, Bahia Falsa, Bahía Verde, Organismo Provincial para el Desarrollo Sostenible, Gobierno de la Provincia de Buenos Aires.

Sprogis KR, Raudino HC, Rankin R, MacLeod CD, Bejder L. 2015. Home range size of adult Indo-Pacific bottlenose dolphins (Tursiops truncatus) in a coastal and estuarine system is habitat and sex-specific. Marine Mammal Science. DOI: $10.1111 / \mathrm{mms} .12260$.

Stenseth NC, Lidicker WZ Jr. 1992. The study of dispersal: a conceptual guide. In Animal Dispersal, Stenseth NC, Lidicker WZ Jr (eds). Springer: Dordrecht, Netherlands; 5-20.

Tagliorette A, Mansur L. 2008. Manual de áreas protegidas, 1st edn. Fundacop, Patagônia Natural: Puerto Madryn, Argentina.

Vermeulen E, Bräger S. 2015. Demographics of the disappearing bottlenose dolphin in argentina: a common species on its way out? PLOS ONE 10: e0119182.

Vermeulen E, Cammareri A. 2009. Residency patterns, abundance and social composition of bottlenose dolphins (Tursiops truncatus) in Bahía San Antonio, Patagonia, Argentina. Aquatic Mammals 35: 379-386.

Wells RS. 1991. The role of long-term study in understanding the social structure of a bottlenose dolphin community. In Dolphin Societies: Discoveries and Puzzles, Pryor K, Norris KS (eds). University of California Press: Berkeley, CA; 199-225.

Wells RS, Hansen LJ, Baldridge A, Dohl TP, Kelly DL, Defran RH. 1990. Distribution, movements and abundance. In The Bottlenose Dolphin, Leatherwood S, Reeves RR (eds). Academic Press: San Diego, CA; 369-434.

Wells RS, Rhinehart HL, Cunningham P, Whaley J, Baran M, Koberna C, Costa DP. 1999. Long distance offshore movements of bottlenose dolphins. Marine Mammal Science 15: 1098-1114.

Wells RS, Scott MD. 1990. Estimating bottlenose dolphin population parameters from individual identification and capture-release techniques. In Individual Recognition of Cetaceans: use of Photo-identification and other Techniques to Estimate Population Parameters, Hammond PS, Mizroch SA, Donovan GP (eds). Report International Whaling Commission, Special Issue 12: 407-416.

Wells RS, Scott MD, Irvine AB. 1987. The social structure of free-ranging bottlenose dolphins. In Current Mammalogy, volume 1, Genoways HH (ed.). Plenum Press: New York; 247-305.

Wilson B, Hammond PS, Thompson PM. 1999. Estimating size and assessing trends in a coastal bottlenose dolphin population. Ecological Applications 9: 288-300.

Wilson B, Reid RJ, Grellier K, Thompson PM, Hammond PS. 2004. Considering the temporal when managing the spatial: a population range expansion impacts protected areas-based management for bottlenose dolphins. Animal Conservation 7: $331-338$

Wood CJ. 1998. Movement of bottlenose dolphins around the southwest coast of Britain. Journal of Zoology 246: 155-163. 
Würsig B. 1978. Occurrence and group organization of Atlantic bottlenose porpoises (Tursiops truncatus) in an Argentine Bay. Biological Bulletin 154: 348-359.

Würsig B, Jefferson TA. 1990. Methods of photo-identification for small cetaceans. Report International Whaling Commission, Special Issue 12: 43-52.
Würsig B, Würsig M. 1977. The photographic determination of group size, composition, and stability of coastal porpoises (Tursiops truncatus). Science 198: 755-756.

Würsig B, Würsig M. 1979. Behavior and ecology of the bottlenose dolphin, Tursiops truncatus, in the South Atlantic. Fishery Bulletin 77: 399-412. 